Acta Universitatis

Nicolai Copernici

Zabytkoznawstwo i Konserwatorstwo XIII, Toruń 2011

Sławomir A. Kamiński

Zakład Konserwacji i Restauracji Sztuki Nowoczesnej UMK

Zuzanna Rozłucka

Zakład Konserwacji Malarstwa i Rzeźby Polichromowanej UMK

\title{
Badania stratygrafii obrazów nowoczesnych na przykładzie twórczości Aleksandra Kobzdeja
}

$\mathrm{M}$ alarstwo nowoczesne i współczesne może pod wieloma względami różnić się od dzieł sztuki dawnej. Najczęściej odmienności dotyczą budowy technicznej, doboru materiałów malarskich i użytych środków wyrazu artystycznego. Często obraz nowoczesny już przy bardzo pobieżnym oglądzie nie przypomina dzieł malowanych tradycyjnie - może kojarzyć się raczej z konstrukcją przestrzenną, jak na przykład Obraz wypekniony sz̧czelina Aleksandra Kobzdeja (il. 1), lub zawierać elementy ruchome czy stanowić bryłę wymagająca specjalnych warunków ekspozycyjnych. Zanim obrazy te staną się przedmiotem prac konserwatorskich i restauratorskich, zwykle są poddawane mniej lub bardziej szczegółowym analizom i badaniom. Zazwyczaj po wstępnych oględzinach możemy podzielić wspomniane dzieła na obrazy malowane zgodnie z warsztatem tradycyjnym lub zawierające rozwiązania charakterystyczne dla warsztatu nowoczesnego. Wyznacznikiem nowoczesności nie jest jedynie okres powstania czy fakt, że jest to praca konkretnego artysty. $\mathrm{Na}$ tym etapie w rozróżnieniu obu warsztatów, często obok analizy wizualnej, pomocne okazuja 
się badania stanu zachowania, które pozwalaja zidentyfikować nietypowy dla tradycyjnego warsztatu malarskiego zakres i wygląd powstałych zniszczeń ${ }^{1}$.

Polskie malarstwo nowoczesne, przeżywające rozkwit w latach 60 . $\mathrm{XX}$ wieku${ }^{2}$, stanowi ciagle aktualne wyzwanie dla badacza i konserwatora, gdyż brakuje szerszego opracowania problematyki technologicznej i konserwatorskiej sztuki tego okresu. Okresu, w którym znaczna część polskich malarzy rozpoczyna swoje poszukiwania w sferze nowoczesnych technik malarskich, stosując techniki własne, techniki mieszane, wprowadzając nowe materiały lub nowe pomysły na stosowanie starych technik i materiałów. Uwagę zwracają dzieła Aleksandra Kobzdeja - jednego z ważniejszych polskich malarzy lat 60., mającego olbrzymi wpływ na życie artystyczne dzięki swojej pracy dydaktycznej i twórczości. W jego malarstwie związek między poszukiwaniem nowych środków wyrazu a rodzącymi się tym samym problemami konserwatorskimi widać szczególnie jaskrawo.

Kobzdej - artysta żywo interesujący się najnowszymi trendami w sztuce - zawsze miał odwage przeprowadzać liczne eksperymenty ${ }^{3}$. Plonem tych przedsięwzięć było powstanie wielu cykli malarskich, różniących się diametralnie techniką wykonania, wykorzystywanymi materiałami i sposobem obrazowania. Wyszedł on od postimpresjonizmu z korzeniami w polskim koloryzmie, z krótkim epizodem kubistycznym, przez realizm socjalistyczny, następnie przez, można powiedzieć, wszystkie formy informelu i obrazy kinetyczne, dotarł do impresjonizmu abstrakcyjnego o silnych wpływach amerykańskich, widocznych w cyklach Szczeliny i Hors

1 Zob. S. A. Kamiński, Konserwacja zapobiegawcza wybranych obrazón wspótczesnych. Ograniczenia i perspektywy, [w:] Konserwacja zapobiegawcza w muzeach, pod red. D. FolgiJanuszewskiej, Warszawa 2007, s. 242-264.

2 J.-C. Lambert, Le miracle polonais, „France Observateur”, 1960, nr 526, s. 24, za: A. Baranowa, Aleksander Kobzdej. Malarstwo jako cena sycia, [w:] Aleksander Kobzdejzmagania z materia, pod red. J. Grabskiego, Kraków-Warszawa 2002, s. 19.

3 A. Kobzdej, Drogi Gościu!, rkps udostępniony autorowi dzięki uprzejmości Muzeum Okręgowego im. Leona Wyczółkowskiego w Bydgoszczy, s. 6. Tekst publikowany w całości w katalogu: Aleksander Kobzdej 1920-1972 (wystawa w 20-lecie śmierci), Warszawa 1992, s. 29-39, oraz we fragmentach w katalogu: Aleksander Kobzdej - zmagania, s. 97-110. 
cadre. W każdym kolejnym cyklu odchodził coraz dalej od tradycyjnych podobrazi i technik malarskich. Zwieńczeniem poszukiwań środków wyrazu artystycznego był wspomniany zbiór prac zatytułowany Hors cadre obrazy bez krosien i ram, w których artysta całkowicie odrzucił tradycyjny warsztat malarski, modelując nie tylko kolor i fakturę warstwy malarskiej,

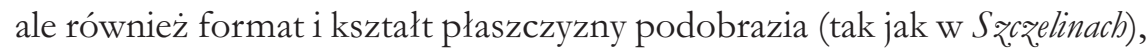
przy czym zmieniając po raz kolejny sposób budowy obrazów, zrezygnował $z$ tradycyjnych podobrazi i stworzył całkowicie własną metodę ich konstruowania. Ta wpisana w nurt światowego malarstwa współczesnego pasja poszerzania języka malarskiego sprawiła, że twórczość tego artysty jest niezwykle cenna także z punktu widzenia konserwatorów i badaczy dzisiejszych technik malarskich.

Rozpoczynając szersze badania dzieł malarstwa nowoczesnego, wykorzystywano doświadczenia zdobyte podczas pracy przy obrazach i rzeźbach wykonanych $\mathrm{w}$ technikach tradycyjnych, często przenosząc je bezpośrednio do analizy dzieł nowszych - co dotyczyło przede wszystkim metod podstawowych. Pojawia się jednak pytanie, na ile metody te moga być przydatne w badaniu sztuki nowoczesnej i współczesnej. Sztuki, która tylko w pewnym stopniu wykorzystuje wypracowane przez pokolenia zasady dobrego warsztatu, odchodząc od nich na rzecz efektu lub świadomie szukając rozwiazzań technologicznych prowadzących do samozniszczenia dzieła. Obok poważnych problemów natury etycznej, związanych z konserwacją takich obrazów, pojawiają się również problemy odnoszące się do ich badania oraz interpretacji uzyskiwanych wyników - na przykład wśród podstawowych metod posługujących się materiałem pobranym bezpośrednio z obiektu, jak mikroskopowa analiza przekrojów poprzecznych próbek, która ciagle jest przecież traktowana jako podstawowy sposób poznawania budowy dzieła ${ }^{4}$. W toku przeprowadzonych przez autorów badań pojawiło się wiele wątpliwości.

4 Przekrój poprzeczny, szlif boczny, zgład (ang. cross-section) - niewielka próbka osadzona najczęściej w żywicy syntetycznej z wypolerowaną płaszczyzną prostopadłą do powierzchni obiektywu mikroskopu umożliwia rozpoznanie układu chronologicznego warstw (za: Stownik polskiej terminologii technik i technologii konserwacji malarstwa sžtalugowego, ściennego i rzę́by polichromowanej, pod red. W. Ślesińskiego, Warszawa 1986, s. 120). 
Uzyskiwane dzięki analizie przekrojów informacje na temat techniki wykonania i chronologii poszczególnych warstw zazwyczaj pozwalają na określenie stratygrafii ${ }^{5}$ obrazu i stanowia punkt wyjścia do kolejnych, szczegółowych badań, jak np. testy mikrochemiczne czy zaawansowane analizy instrumentalne, umożliwiające bardziej szczegółową identyfikację materiałów ${ }^{6}$. W mikroskopowych badaniach stratygrafii stosuje się metodykę wypracowaną w latach 30. i rozwijaną w latach 50. XX wieku? Ewolucja metodyki tych analiz skupia się w ostatnim czasie na stale poszerzanej gamie żywic do osadzania próbek oraz modernizacji sposobu odsłaniania przekrojów ${ }^{8}$. Odrębny nurt stanowią techniki pozwalające na wykorzystanie do obserwacji przekrojów innych źródeł światła, na przykład promieniowania UV, umożliwiającego bardziej szczegółową interpretację przekrojów, zarówno w zakresie stratygrafii warstw, jak i ich składu?

Mikroskopowa analiza przekrojów poprzecznych próbek, stając się bardzo skutecznym narzędziem poznawczym, odsłoniła tajniki tradycyjnego warsztatu malarskiego. Na ile zdobywane przez dziesiątki lat doświadczenia można przenieść na grunt malarstwa nowoczesnego oraz jakie trudności moga wyniknąć z innej budowy technicznej tych dzieł?

5 Stratygrafia (ang. stratigraphy) - symbol graficzny ilustrujący budowę obiektu zabytkowego, układ wszystkich występujących w nim warstw technologicznych, odzwierciedlających ich chronologię, sporządzony na podstawie badań sondażowych, obserwacji szlifów bocznych i in. Stratygrafia może odnosić się do fragmentu obiektu (miejscowa, lokalna) lub zawierać uporządkowane informacje uzyskane ze stratygrafii miejscowych (zbiorcza) (za: ibidem).

6 Szerzej zob. J. Rogóż, Zastosowanie technik nieniszczacych w badaniach konserwatorskich malowidet ściennych, Toruń 2009.

7 A. Eibner, L'examen microchimique des agglutinants, „Museion”, 20.04.1932, s. 5-23; R. J. Gettens, The cross-sectioning of paint film, „Technical Studies in the Field of Fine Arts", 1936-1937, vol. 5, s. 18-22; J. Plesters, The Preparation and Study of Paint Cross-sections, „The Museums Journal”, 1954, 543, 4, s. 97-101; idem, Cross-section and Chemical Analysis of Paint Samples, „Studies in Conservation”, 1956, vol. 2, no. 3, s. $110-132$.

8 Zob. F. Waetig, Gießharzsysteme zum Einbetten von Proben, „Restauro”, 3/93; I. N. M. Wainwright, Sampling, Cross-section Preparation and Photomicrography: Paintings and Polychromes, Canadian Institut Draft Notes, 12.04.1988 [mps].

9 Z. Rozłucka, M. Roznerska, J. Arszyńska, Mikroskopia fluorescencyjna. Zastosowanie w badaniu budowy i procesów konserwacji malarstwa sz̨talugowego, Toruń 2000. 
Problemy napotkane podczas badania obrazów artysty, związane $z$ interpretacją budowy warstw malarskich i ich chronologii, sprowokowały autorów artykułu do przedstawienia rozważań na temat przydatności omawianej metody w analizie obrazów nowoczesnych, których wykonanie opiera się na nowoczesnym warsztacie malarskim, i zaprezentowania ważniejszych wniosków. Choć dotyczą one twórczości jednego malarza, to ze względu na specyfikę jego warsztatu pozwalają również poszerzyć wiedzę o problematyce konserwatorskiej obrazów nowoczesnych innych artystów, wykonywanych $\mathrm{w}$ technikach własnych, mieszanych lub z zastosowaniem spoiw syntetycznych.

Jedna z cech charakterystycznych badanych dzieł jest ich duża różnorodność materiałowa, wynikająca między innymi z nowego spojrzenia artysty na funkcję podobrazia i przyznanie mu pełnoprawnego statusu tworzywa artystycznego ${ }^{10}$. Kobzdej, począwszy od informeli, aż do Hors cadre, pracował nad włączeniem przestrzeni w strukturę obrazu. Aby osiagnać większa przestrzenność swoich dzieł, początkowo wprowadził wzbogacające fakturę aplikacje $z$ materiałów celulozowych w standardowe podobrazia płócienne. W kolejnych cyklach wykonywał samodzielnie starannie przemyślane konstrukcje podobrazi, poczattkowo drewniane, następnie druciane, często posługując się przygotowanymi wcześniej projektami i modelami. Te niekiedy bardzo rozbudowane przestrzennie formy podobrazi umożliwiają obrazom nawiązanie dialogu z przestrzenią (zob. il. 1).

W celu zilustrowania wspomnianych problemów poniżej przytoczono wyniki niewielkiej części badań mikroskopowych przekrojów poprzecznych próbek pobranych z obrazów należących do różnych cykli malarskich Aleksandra Kobzdeja ${ }^{11}$. Analizę każdego przekroju przeprowadzano dwukrotnie: po raz pierwszy - po pobraniu materiału badawczego, i drugi raz - po uzyskaniu wyników wszystkich badań uzupełniających, które w większości potwierdzały pierwotną interpretację.

10 Zob. Konserwacja zapobiegawcza w muzeach. Właśnie elementy podobrazi często odnajdujemy w przekrojach poprzecznych warstwy malarskiej.

11 S. A. Kamiński, Problematyka technologiczna i konserwatorska malarstwa Aleksandra Kobzdeja, praca doktorska napisana pod kier. prof. dr. hab. D. Markowskiego, Toruń 2007 [mps]. 



stwierdzono obecność drutów stalowych. Jest to jeden z charakterystycznych materiałów wykorzystywanych przez artystę do budowy początkowo elementów podobrazi, jak we wspomnianym zbiorze dzieł czy w cyklu Wgłebienia $^{13}$. W obrazach Hors cadre drut, a właściwie siatka druciana, stanie się podstawowym elementem nośnym podobrazi. Na przekroju poprzecznym próbki nr $26^{14} \mathrm{w}$ świetle VIS (il. 2) i w promieniach UV (il. 2b) widać przekrój takiego drutu otoczonego brązową masa. W promieniach UV obserwujemy wygaszanie fluorescencji przez metal i produkty korozji oraz jasną silną fluorescencję żywicy poliestrowej otaczającej drut i stanowiącej spoiwo ciemnobrazzowo zabarwionej pulpy celulozowej. W tym przypadku zdjęcia mikroskopowe dobrze ilustrują charakterystyczne cechy budowy obrazu, choć nie można tu mówić o chronologii warstw.

Inny materiał, nieużywany w tej formie w tradycyjnym warsztacie malarskim ${ }^{15}$, spotykamy w Obrazie przestrzennym wysokim ${ }^{16}$, należącym również do cyklu Szczeliny, będącym przykładem dalekiego odejścia od malarstwa sztalugowego rozumianego tradycyjnie. Obraz ten jest konstrukcja wolno stojąca, przeznaczoną do oglądania ze wszystkich stron - prawdopodobnie użycie przez artystę w tytule określenia „obraz” jest pytaniem skierowanym do odbiorcy o granice jego poszukiwań artystycznych. Należy on

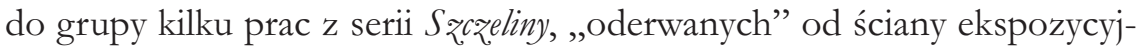

12 Szeroka szczelina w bielach, 1969, własn. Muzeum Okręgowe im. Leona Wyczółkowskiego w Bydgoszczy, nr inw. MW/855/MOB.

13 Według najnowszych badań twórczości Kobzdeja pomiędzy cyklami Szczeliny i Hors cadre powstał krótki cykl Wgtebienia, stanowiący ogniwo pośrednie (zob. S. A. Kamiński, Problematyka konserwatorska nowoczesnego warsztatu malarskiego na prayktadzie wybranych dziet A. Kobzdeja. Prace konserwatorskie i restauratorskie, [w:] D. Markowski, S. A. Kamiński, M. Wachowiak, Wybrane zagadnienia konserwacji i restauracji sz̨tuki nowoczesnej, Torún 2010, s. 202, fot. 12, 13, 14, 15).

14 Numeracja próbek odpowiada numeracji przyjętej w rozprawie doktorskiej autora: S. A. Kamiński, Problematyka technologiczna.

15 Materiały celulozowe stosowano od wieków w różnej postaci jako podobrazia lub ich elementy, natomiast Kobzdej wykorzystał pulpe celulozową w warstwie malarskiej jako wypełniacz umożliwiający osiaganie efektów fakturalnych.

16 Obraz przestrzenny wysoki, 1968, własn. Muzeum Okręgowe im. Leona Wyczółkowskiego w Bydgoszczy, nr inw. MW/976/MOB. 
nej ${ }^{17}$. Na przekroju poprzecznym próbki nr 22 (il. 3a i b) widać włókna celulozowe o białej fluorescencji, obecne w masie składającej się z glinki z dodatkiem bieli tytanowej, na której leży warstwa farby zawierająca biel cynkową i warstwę oranżu syntetycznego. Zastosowana tutaj metoda badawcza pozwoliła na rozróżnienie warstw technologicznych - czerwonej i białej warstwy malarskiej od warstwy pulpy celulozowej, co umożliwiło prawidłowe ustalenie jedynie stratygrafii lokalnej, gdyż stopień złożoności budowy całego obrazu wymaga, w celu określenia stratygrafii zbiorczej, znacznego poszerzenia pakietu badań.

Z kolei w obrazie Blekitne wnetrze No $12^{18}$ - kolejnej pracy z serii Szczeliny, powstałej jako jedno z ostatnich dzieł cyklu - dominującą rolę odgrywa kompozycja wypełniająca szczelinę. Jej ukształtowanie i powierzchnia wyraźnie zapowiadają następny zbiór prac artysty. Stratygrafia próbki nr 29 pobranej z omawianego obrazu w świetle VIS (il. 4a) jest słabo czytelna: warstwy syntetycznej czerwieni i błękitna warstwa ultramaryny z czernia leżą na barwionym podłożu. Dopiero w promieniach UV (il. 4b) uczytelnia się warstwowa budowa próbki: trójwarstwowe opracowanie malarskie na spoiwie syntetycznym leżące na podłożu z ligniny przesyconej czerwoną i błękitną farbą o spoiwie wodnym. Zastosowanie obserwacji mikroskopowej przekroju poprzecznego pozwoliło tylko częściowo rozpoznać stratygrafię - wyłącznie w zakresie warstw górnych, nie wyjaśniając przyczyny technicznej chaotycznego rozłożenia warstw spodnich próbki.

W części prac spotykamy sytuację, w której materiały utożsamiane w warsztacie tradycyjnym z podłożem mogą stanowić nawet ostatnia, najwyższą warstwę malarska. Jest tak między innymi w obrazie Komposy$c j a^{19}$, należącym stylistycznie do cyklu informel, jednak o nieco innej niż pozostałe informele budowie. Zwykle w dziełach tych artysta posługiwał się licznymi dodatkami do warstwy malarskiej. Pod względem braku takich dodatków obraz jest wyjątkowy - może jest to spowodowane jego

17 Inne przykłady to: Bez. tytułu (czerwono-złoty), 1970; Rama z. źótcieniem, 1970 (zob. Aleksander Kobzdej - zmagania, s. 212, 213).

18 Btekitne wnetrze No 12, 1970, własn. Muzeum Okręgowe w Toruniu, nr inw. $\mathrm{MT} / \mathrm{M} / 782 / \mathrm{N}$.

19 Kompozycja, 1965, własn. Muzeum Okręgowe im. Leona Wyczółkowskiego w Bydgoszczy, nr inw. MW/1658/MOB. 
historią. Stanowił on część obrazu mobilnego powstałego w czasie pracy artysty w Hamburgu. Tę prostszą budowę ilustruje przekrój poprzeczny próbki nr 13 (il. 5a): górna warstwa - bieli - to kreda w spoiwie emulsyjnym syntetycznym, winylowym, leżąca na warstwach olejnych - ziemia zielona rozbielona biela tytanowa, która leży na błękitnej, zawierającej ultramarynę oraz kilka innych pigmentów, u dołu jest ona bardziej oranżowa - widać dodatek bieli cynkowej, pod nią leży również warstwa zielona zbudowana dwuwarstwowo: do dolnej warstwy dodano czerń. Obserwacja w promieniach UV (il. 5b) pozwala na rozróżnienie w próbce dwóch rodzajów bieli: bieli cynkowej o silnej jasnej fluorescencji i bieli tytanowej o fluorescencji przytłumionej. Omawiany przykład pokrycia warstw tłustych warstwami chudymi powoduje powstawanie na powierzchni obrazu charakterystycznych kraterów, co widać na makrofotografii (il. 6). Ta ostatnia warstwa została dodana przez artystę, kiedy obraz przestał być elementem większej pracy i miał funkcjonować jako dzieło autonomiczne. Fotografie mikroskopowe przekroju poprzecznego próbki bardzo dobrze ilustrują warstwową budowę obrazu - w tym przypadku zastosowana metoda badawcza w wyczerpujący sposób oddaje stratygrafię, ukazując również jej aspekt chronologiczny, natomiast bez odpowiedzi pozostaje pytanie o rolę ostatniej warstwy.

Warto zwrócić uwagę na powtarzający się w wielu obrazach problem z wyborem miejsca pobrania reprezentatywnej próbki, która właściwie odzwierciedli złożoność budowy obrazu (il. 1). W obrazie Stary bræeg ${ }^{20}$, jednym z wcześniejszych informeli o bardzo złożonej, przez liczne aplikacje, budowie, przekrój poprzeczny próbki nr 6 (il. 7a, b) ukazuje mało skomplikowaną trójwarstwową strukturę, składającą się z dwóch olejnych warstw malarskich leżących na podłożu papierowym (czytelnym w promieniach UV), przesyconym czerwienią kobaltowa. Taka sekwencja warstw powtarza się w wielu miejscach na powierzchni obrazu, dopiero konfrontacja z makrofotografią (il. 8) pozwala prawidłowo odczytać przestrzenne ukształtowanie warstwy malarskiej w tych obszarach. Natomiast poprawną interpretację stratygrafii utrudnia brak odpowiednio dokładnej dokumentacji procesu twórczego i wcześniejszego wyglądu dzieła - w tym

20 Stary brzeg, 1961, własn. Muzeum Okręgowe w Toruniu, nr inw. MT/ $/ \mathrm{M} / 485 / \mathrm{N}$. 
przypadku wygląd pewnych partii obrazu sugeruje ubytki aplikacji i warstwy malarskiej. Przykład ten ukazuje sytuację, w której zwiększanie liczby pobieranych próbek nie wystarczy do zbudowania prawidłowej stratygrafii zbiorczej. Warunkiem niezbędnym staje się poszerzenie zakresu badań.

Inaczej jest wówczas, gdy informacji o budowie obrazu, zdobytych w wyniku przeprowadzonej analizy wizualnej i badania stanu zachowania, nie udaje się potwierdzić na przekrojach stratygraficznych. Ma na to wpływ wiele czynników: brak możliwości pobrania próbki w trudno dostępnych obszarach obrazów przestrzennych, nieprzewidywalna złożoność budowy obrazu w danym miejscu, lub wręcz scalenie w jednym dziele kilku różnych „obrazów”, brak struktury warstwowej, z czym spotykano się w przypadku obrazów z cyklu $S$ žczeliny.

Artyści nowocześni, znani ze swej awangardowej twórczości, w niektórych cyklach malarskich mogą być wierni tradycyjnemu warsztatowi, co można było zaobserwować na przykładzie twórczości Kobzdeja. Wśród badanych dzieł jego autorstwa znalazły się również obrazy malowane zgodnie z warsztatem tradycyjnym, jak Zariniety indy $k^{21}$ i Portret Matk $i^{22}$, pochodzace $z$ okresu realistycznego - ustalenie ich stratygrafii nie stwarzało takich problemów jak te opisane wcześniej.

W wyniku przeprowadzonych badań można stwierdzić, że mikroskopowa analiza przekrojów poprzecznych próbek pobranych z obrazów nowoczesnych, malowanych w technikach nietradycyjnych, umożliwia rozpoznanie budowy technicznej tych obrazów, chociaż w ograniczonym zakresie. Im budowa dzieła bardziej odbiegała od warsztatu tradycyjnego, tym więcej wątpliwości i trudności pojawiało się podczas interpretacji przekrojów.

W przypadku dzieł powstałych $\mathrm{w}$ technikach warsztatu nowoczesnego układy warstw często fragmentarycznie odzwierciedlają budowę

21 Zarżniety indyke, 1951, własn. Muzeum Okręgowe im. Leona Wyczółkowskiego w Bydgoszczy, nr inw. MW/1494/MOB.

22 Portret Matki, 1953, własn. Muzeum Okręgowe im. Leona yczółkowskiego w Bydgoszczy, nr inw. MW/855/MOB. Muzeum Okręgowe im. Leona Wyczółkowskiego w Bydgoszczy, nr inw. MW/1495/MOB. 
obrazów, ale fragmentaryczność ta nie wynika jedynie z lokalnej budowy miejsca pobrania próbki, tak jak najczęściej jest w przypadku obrazów malowanych w technikach tradycyjnych, lecz z innego procesu twórczego, braku możliwości pobrania właściwej próbki, przypadkowego układu warstw powstałego jako efekt uboczny zastosowanej techniki pracy lub specyficznego doboru spoiw farb. Zazwyczaj obrazy powstałe według zasad warsztatu nowoczesnego zawierają również elementy warsztatu tradycyjnego, a ich stratygrafia lokalna zwykle nie odzwierciedla stratygrafii zbiorczej.

W malarstwie dawnym, zgodnie $z$ definicja $a^{23}$, stratygrafia warstw mówi o chronologii ich powstawania oraz chronologii zmian wywołanych ingerencjami konserwatorów, natomiast w malarstwie nowoczesnym układ ten może wynikać też z innych powodów. Usytuowanie danej warstwy w przekroju stratygraficznym może przeczyć chronologii, świadczyć nie o kolejności powstania danej warstwy, ale na przykład o jej rozlewności lub użytej technice pracy z tworzywem (il. 9). Należy więc zadać pytanie, czy numerowanie warstw w przekrojach stratygraficznych w takiej sytuacji ma jeszcze sens? Czy będzie prowadzić do nieporozumień? Stąd sugestia, aby traktować zwyczajową numerację warstw jedynie jako sposób ich znakowania, a nie porządkowania chronologicznego.

Analizując stratygrafię obrazów współczesnych, najczęściej spotykamy większą różnorodność użytych materiałów, zarówno tworzących warstwy malarskie, jak i podobrazia; zwykle są wykorzystywane materiały obce w pojęciu sztuki dawnej czy materiały syntetyczne. Następuje zatarcie podziału pomiędzy podobraziem i warstwą malarska, natomiast ubytki nie zawsze świadczą o zniszczeniach - czasami mogą być efektem zamierzonym i wynikać z procesu twórczego.

Autorzy skłaniaja się ku stwierdzeniu, że stosowanie opisywanej metody przy tego rodzaju obiektach, prawidłowe interpretowanie otrzymywanych wyników i w efekcie - konstruowanie stratygrafii zbiorczej obiektu wymagaja jej uzupełnienia i uwzględnienia szeregu zastrzeżeń, z których najważniejsze to:

- szczegółowo i prawidłowo przeprowadzona analiza wizualna i ocena stanu zachowania obrazu;

$23 \quad$ Zob. przyp. 2. 
- dokumentacja miejsc pobrania próbek uzupełniona o zdjęcia makroskopowe w kontekście miejsca, czy nawet obszaru pobrania próbki;

- wykorzystywanie wszelkich dostępnych informacji uzyskanych w toku badań historyczno-artystycznych; o ile to możliwe, sięganie do źródeł pochodzących z otoczenia artysty ${ }^{24}$ - mogą one poważnie zmienić interpretację badań, szczególnie istotne są dane pozwalające rozróżnić działania artysty od efektów procesu niszczenia;

- poszerzenie asortymentu badań technologicznych, w tym szczególnie materiałów syntetycznych, zarówno artystycznych, jak i pozaartystycznych.

Reasumując, wyniki przeprowadzonych badań upoważniają autorów do potwierdzenia przydatności metody mikroskopowej analizy przekrojów poprzecznych próbek do badań stratygrafii obrazów nowoczesnych z uwzględnieniem omówionych powyżej zastrzeżeń.

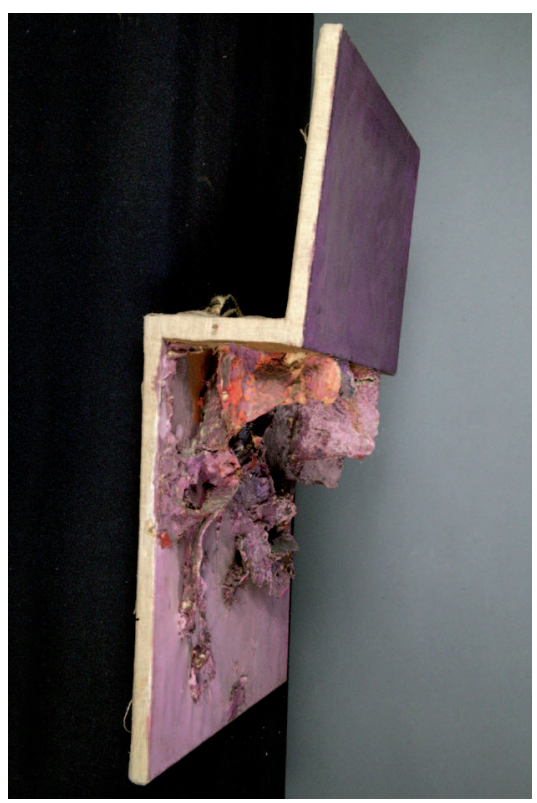

Il. 1. Obraz, wypetniony szezelina, widok z boku (fot. S. A. Kamiński)

24 I. Szmelter, M. Jadzińska, Zachowaí dla przyszłości - artyści warszawscy, Warszawa 2003, film w formacie mpg. 


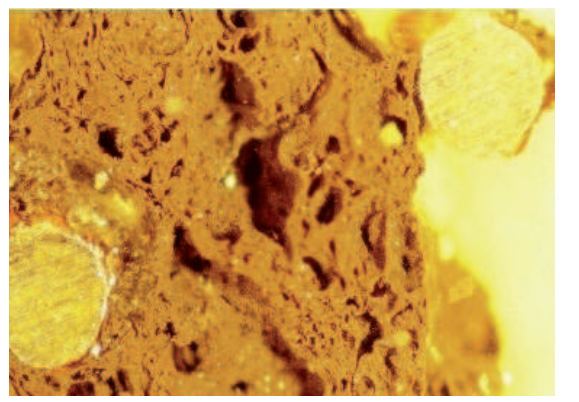

b)

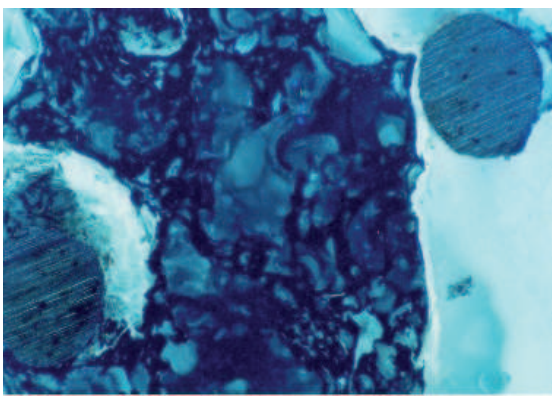

Il. 2. Przekrój poprzeczny próbki 26 z obrazu Szeroka szçelina w bielach, którego budowy nie można utożsamiać z układem warstw (fot. Z. Rozłucka):

a) w świetle VIS widać przekrój drutu stalowego otoczonego brązową masa;

b) w promieniach UV metal wygasza fluorescencję, obok widać białą fluorescencję żywicy syntetycznej

a)

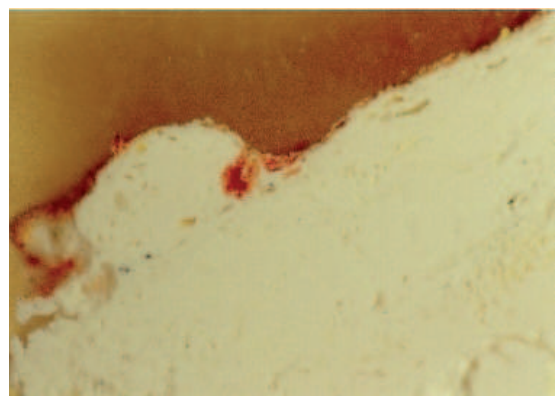

b)

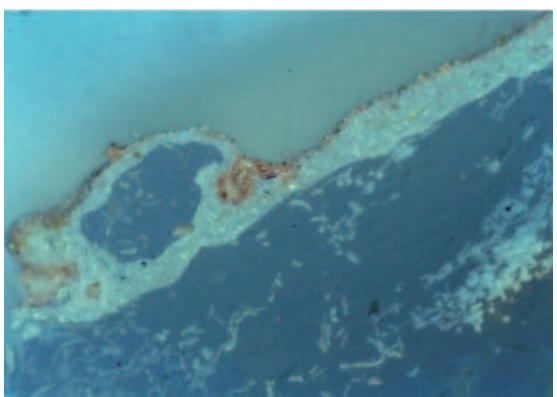

Il. 3. Przekrój poprzeczny próbki 22 z Obrazu przestrzennego wysokiego (fot. Z. Rozłucka):

a) w świetle VIS widać, że na białej warstwie leży czerwona warstwa malarska o spoiwie syntetycznym;

b) w promieniach UV ujawnia się rzeczywista stratygrafia próbki - można odróżnić białą warstwę malarską z bielą cynkową o charakterystycznej białej fluorescencji od masy z glinki, bieli tytanowej w spoiwie syntetycznym o błękitnej fluorescencji, z dodatkiem jasno świecących włókien celulozowych 
a)

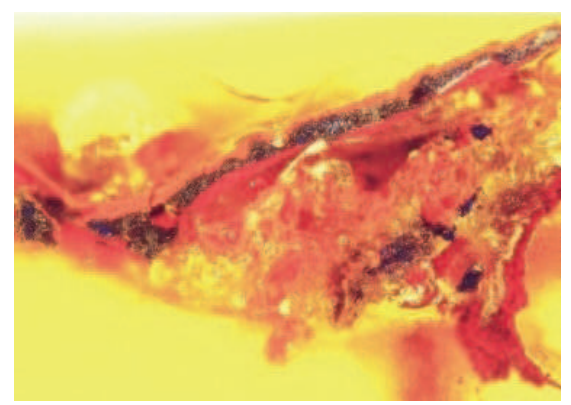

b)

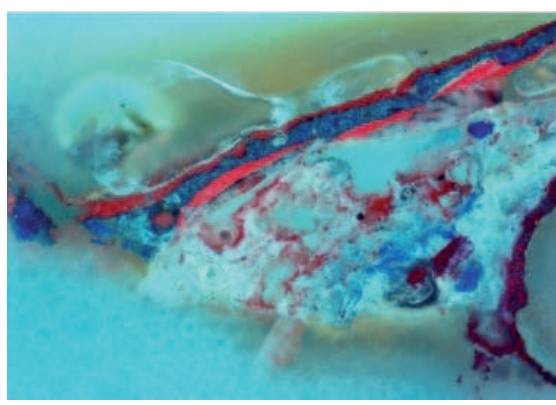

Il. 4. Przekrój poprzeczny próbki 29 z obrazu B tękitne wnętrze No 12 o trudno czytelnej, nieuporządkowanej strukturze (fot. Z. Rozłucka):

a) w świetle VIS widoczny konglomerat warstw czerwonych i niebieskich oraz niezidentyfikowanej masy;

b) w promieniach UV uczytelnia się warstwowa struktura górnej partii próbki, dzięki jasnej fluorescencji pulpy celulozowej można wyodrębnić opracowania malarskie

a)



b)



Il. 5. Przekrój poprzeczny próbki 13 z obrazu Kompozycja. Widoczne wyraźne uwarstwienie próbki (fot. Z. Rozłucka):

a) w świetle VIS widać białą warstwę leżącą na zielonych i szarych warstwach;

b) w promieniach UV dzięki charakterystycznej fluorescencji bieli cynkowej można wyróżnić warstwy, w których jest ona obecna, oraz z powodu wygaszania fluorescencji warstwy z zawartościa zielonych pigmentów chromowych; wierzchnia warstwa bieli zwraca uwage odmiennym charakterem, co uzasadnia kredowy wypełniacz i chude syntetyczne spoiwo 


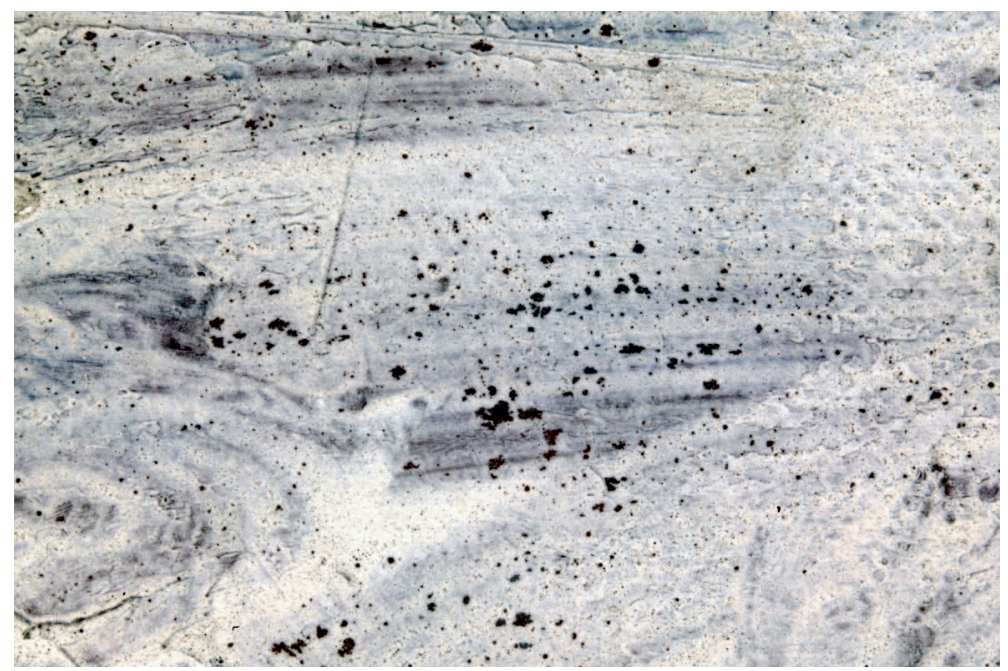

Il. 6. Kompozycja. Makrofotografia - fragment lica. Widoczne charakterystyczne efekty założenia warstwy chudej na tłustą (fot. S. A. Kamiński)

a)

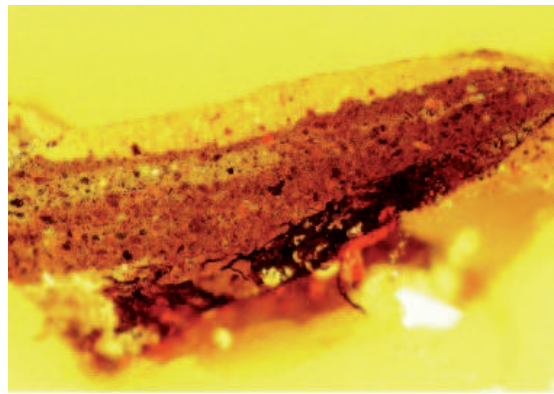

b)

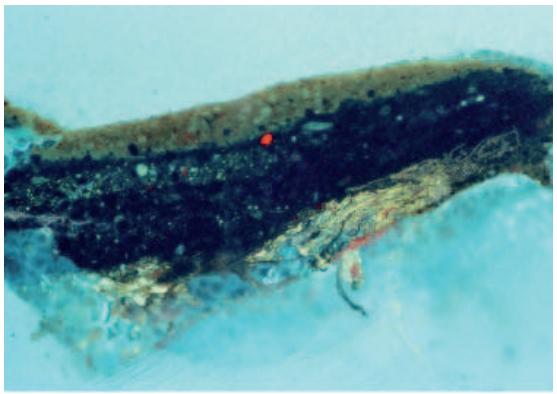

Il. 7. Próbka 6 z obrazu Stary bræeg o dość uporządkowanej strukturze warstwowej (fot. Z. Rozłucka):

a) w świetle VIS widać żółtobrunatne opracowanie na ciemnoczerwonej warstwie;

b) w promieniach UV dzięki jasnej fluorescencji ujawnia się podłoże papierowe zabarwione czerwienią kobaltową 


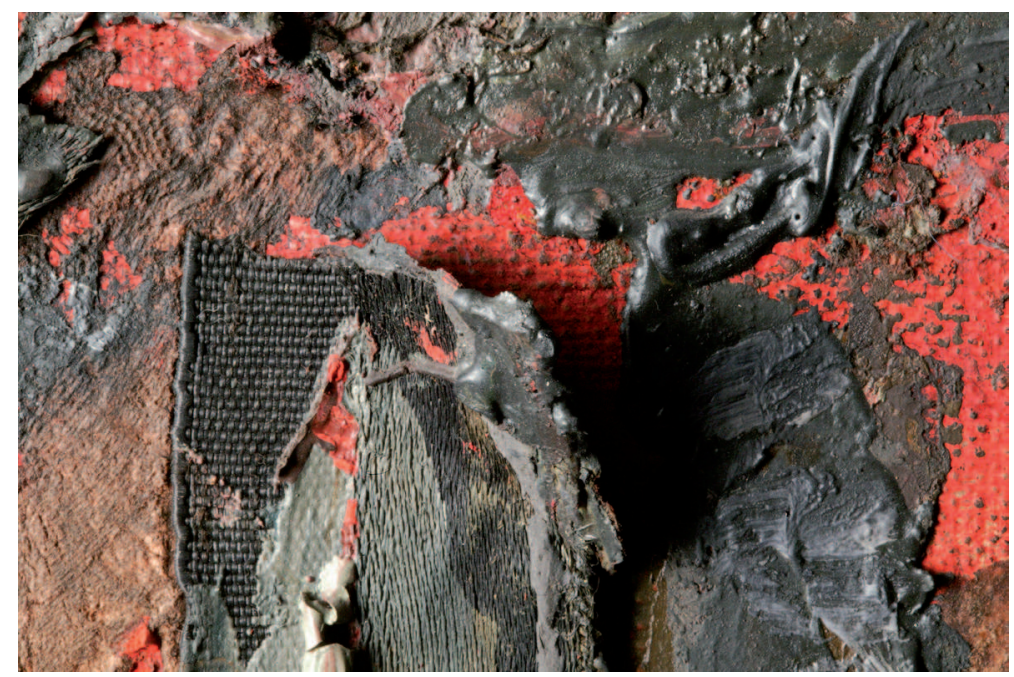

Il. 8. Stary breeg. Fragment lica - widoczna silnie rozbudowana w przestrzeni warstwa malarska $z$ aplikacjami z materiałów pozamalarskich (fot. S. A. Kamiński)

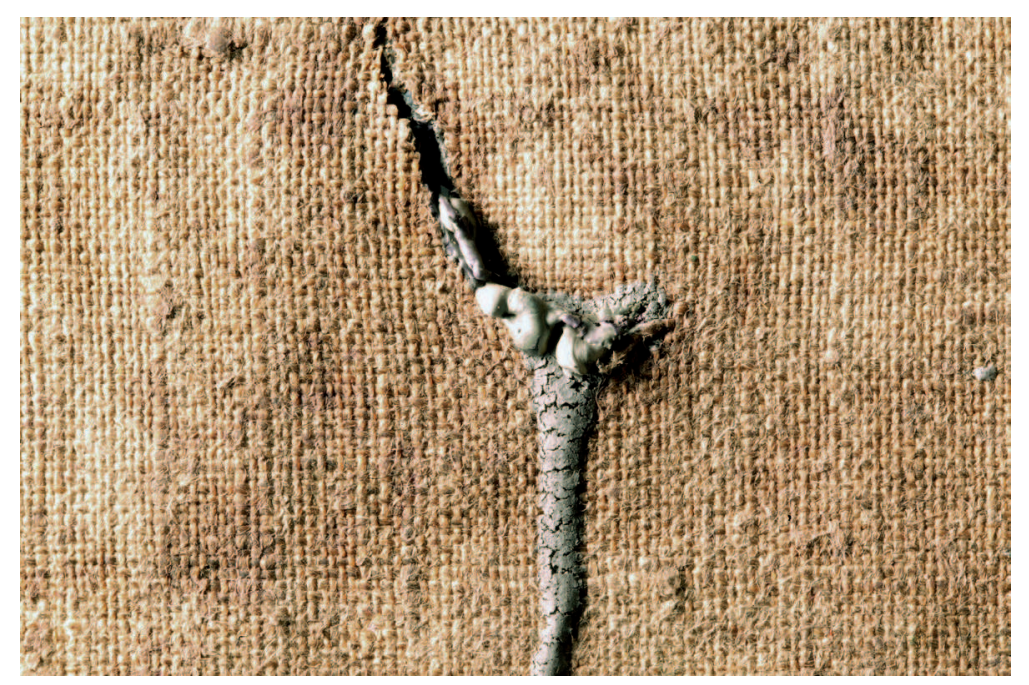

Il. 9. Grota srebra. Fragment odwrocia - rozcięcie płótna powstałe podczas malowania szpachlą, przez które wypłynęła farba (fot. S. A. Kamiński) 


\section{Summary}

\section{Examination of the stratigraphy of modern paintings exemplified by the artistic output of Aleksander Kobzdej}

The authors, within the framework of a larger project, carried out examination of modern paintings by Aleksander Kobzdej. This paper comprises discussion on the technical structure of paintings by the artist mentioned above and the results of examination of the stratigraphy of selected paintings. The results of microscopic examination of cross sections of samples taken from those paintings are illustrated with photographs in visible and UV-light. The conclusions concern applicability of microscopic method of examining the stratigraphy of samples for investigating the structure of modern paintings. Applicability of the mentioned technique also in this field has been confirmed, provided that the following conditions are met: broadening photographic documentation of the location of collected samples - the role of macro-photographs, increasing the assortment of the methods of assessing the condition of paintings as well as broadening the spectrum of methods of examining the composition of synthetic substances both artist's materials and others. 